\title{
Sexual Violence and Sainthood: A Critical Study of Our Lady of Alice Bhatti
}

\author{
Sourav Paul ${ }^{1}$ and Dr Shri Krishan Rai ${ }^{2}$
}

${ }^{1}$ UGC Junior Research Fellow, Department of Humanities and Social Sciences, National Institute of Technology Durgapur, India. ORCID: 0ooo-00o2-5921-2863.

Email:paul.sou.7@gmail.com

${ }^{2}$ Assistant Professor, Department of Humanities and Social Sciences, National Institute of

Technology Durgapur, India. Email: srikrishanrai4@gmail.com

Received April 27, 2018; Revised September 30, 2018: Accepted October 27, 2018; Published October $27,2018$.

\begin{abstract}
The study explores how the eponymous novel Our Lady of Alice Bhatti (2011) by Mohammed Hanif takes the stance of rediscovering the multifaceted strains of sexual violence as on the backdrop of sainthood. The protagonist (Alice) executes saintly miracles with her unnerving gifts for which superficially she is perceived as a divine human being if not worshipped. But nothing, not even her supernatural skill set, can restrain her from being a victim of sexual violence. Rather spiritual holiness is shattered by the intimidation of the body. Alice's mystic powers are treated like a witch's necromancy than a curer's touch for which she is prejudiced as an easily accessible flesh. This preoccupation of terror is not merely the creed for sex but the greed for violence (hence power). Finding common grounds between two religions on the basis of humanity and nature the paper sounds true to its venture of the issue of sexual violence along with its turnovers in the social, political and cultural dynamism of sainthood.
\end{abstract}

Keywords: Sexual violence, sainthood, holiness, body, terror, necromancy.

\section{Introduction}

"Between patriarchy and imperialism, subject constitution and object formation. The figure of the woman disappears ...there is no place from where a sexed Subaltern can speak". Gayatri Chakravorty Spivak, “Can the Subaltern Speak?” (1988, p.307).

Denuded of the slapstick and magic realist literary effects, Our Lady of Alice Bhatti (2011) is an acerbic narrative on the socially virulent violence on women and girls in Pakistan (Sehgal, 2012). It is a traumatizing abecedary of how women are hunted, choked and chopped up and thrown away by the male-centered existence of a nation-state. The critical study of this deft and evil little novel does not only render the counteraction of a subjugated woman. It also foregrounds the problematic of a saintly lady's odysseys in the whirlwinds of libidinous enchantment a male gaze

(c) AesthetixMS 2018. This Open Access article is published under a Creative Commons Attribution Non-Commercial 4.0 International License (http://creativecommons.org/licenses/by-nc/4.o/), which permits non-commercial re-use, distribution, and reproduction in any medium, provided the original work is properly cited. For citation use the DOI. For commercial re-use, please contact editor@rupkatha.com. 
encapsulates. Even the healing touch of sainthood fails to nullify the lustful desire eternally associated with a 'sister'. In an attempt to understand varying degrees of sexual violence it shows life in its truest siege under the world's oldest and most deadly instinct of terrorism -

“... there was not a single day - not a single day - when she (Alice) didn't see a woman shot or hacked, strangled or suffocated, poisoned or burnt, hanged or buried alive. Suspicious husband, brother protecting his honor, father protecting his honor, son protecting his honor, jilted lover avenging his honor, feuding farmers settling their water disputes, moneylenders collecting their interest: most of life's arguments, it seemed, got settled by doing various things to a woman's body." (Hanif, 2011 p. 142)

As the title indicates the novel represents the story of its protagonist Alice Bhatti, daughter of Joseph Bhatti and a Catholic nurse in present day Pakistan. Released forthwith out of prison and despite challenging odds she manages to wrangle a job of Junior Supplementary Nurse at Karachi's Sacred Heart Hospital for All Ailments, a cesspit of gangrene and incompetence. The "delivery room is a gambling den", identified itself by the grim sobriquet 'baby slaughterhouse', the senior sister Hina Alvi informs where "(E)veryone comes out a loser". In the course of events she seems to possess unnerving potentialities - mysterious healing powers and the ability to predict future especially how one would die. She performs miracles with her faith in Lord Yassoo that are why the residents of the psychiatric ward love her. Every wall of the Sacred Heart hospital echoes her sainthood after she miraculously turns a dead infant alive. But nothing, not even her supernatural skill set, can restrain her from being a victim of sexual abuse where the larger canvas of terrorism plays an insidious role within. Even remaining 'an old spinster' in a 'nation of perverts' would also not suffice enough to avoid molestation.

\section{Merging Sainthood and Virginity}

Representing sainthood the sexuality has always been forecast than the textuality of it. The novelist depicts the truest nature of lewd instincts which a male gaze incorporates. And in case of a working girl or more specifically the medical profession, a 'sister' instinctively is considered easy to penetrate by a lustful man thus succumbing her into a subaltern. Alice's subalternity is synonymous to the condition of any working girl in a terror-ridden nation-state of Pakistan no doubt. Sainthood might inevitably encapsulates virginity (physical/moral) the celibacy is more austere in case of authenticating a feminine identity than to their male counterparts. According to Robert Bartlett, virginity "always mattered more in the case of women... there are cases of male saints praised for maintaining their virginity, but they did not form a large, identifiable category in the way that female virgins did." (Bartlett, 2013 p.202) This is what is meant by 'obscure rituals and intricate rules' of validating Alice's sainthood in the collective consciousness of the contemporary society.

In his classic study Sainthood in the Later Middle Ages André Vauchez investigates the discourse of sainthood. Aligning with the post-Gregorian drive to monasticize the episcopate he states it to be leading to increased emphasis on the celibacy and virginity of certain bishops. He highlights that the episcopal office was believed to be the central component of episcopal sainthood. Despite the recent upheaval in scholarly interest in clerical masculinity and sexuality, historians of gender and sexuality have done hardly little to contradict Vauchez's findings. This historiographical failure to consider virginity as a significant episcopal quality largely attributes to the main factor of this study - whether virginity is still taken primarily as a female attribute, if not how it is conditioned to the traumatic socio-political condition in the South Asian continents. 
Alice's love-marriage could not satiate the skeptical voice of her husband's friends - " 'We were looking for a virgin for this special occasion, but then Inspector Malangi reminded us that our bhabi is Yasoo's follower, so we went looking for a Christian virgin. And you know what the pimp said? He said the last one was taken more than two thousand years ago.' " (Hanif, 2011 p.149)

\section{Sainthood and subalternity}

The study finds out the jeopardy of Alice's sainthood as a healer of death and decadence in opposite of her subalternity for being a lady, sister and Christian altogether. That is where the novel deals with life in its raw form and deconstructs it to the very core of human instincts and his social values. Alice is always dealt as a body, a lump of flesh irrespective of a human being. The following quote can attest this - "Alice's body is one of those miracles of malnourishment, which has resulted in a thin, brittle bone structure with overgrown breasts." (Hanif, 2011 p.137) She is definitively rumored as a divine human being but her sexuality precedes humanity. Her miraculous presence is what sought by the patients and staffs but her bosoms foresee her halo. She is intensively called for a bed than her sexual identity forbade. The erstwhile serendipity of sainthood is thus critically requestioned and shattered in a troubled testimony of practical facts by Mohammed Hanif - "(L)ife has taught Alice Bhatti that every little step forward in life is preceded by a ritual humiliation.” (Hanif, 2011 p.81)

The priestly celebration of a saint is not an unproblematic thing since it requires a level of ritual purity that is quite difficult for a mortal man to maintain. From the twelfth century onwards, theologians became increasingly troubled by problem of "...the potential pollution of the priestly body by involuntary nocturnal emissions of semen." (Murray, 1997 pp. 1-26) Whereas the uncleanness, as it is called, of girls at puberty and the sanctity of holy men do not, to the primitive mind, differ materially from each other. "They are different only in manifestations of the same mysterious energy which, like energy in general, is in itself neither good nor bad, but becomes beneficent or maleficent according to its application." (Walters, 2012 p.607) Thus the validity of Alice's wedding is not exempted from allegation in spite of her poverty and suddenness of the incident - "What kind of wedding is this where the only evidence is a box of cheap sweets? They are probably living in sin." (Hanif, 2011 p.225)

\section{Of sexual violence}

The femininity of Alice is not only problematized with her sainthood rather the two discourses are laid bare in a mode of confrontation. Alice sounds self-aware of this cult sexuality notwithstanding perceived as a divinity, if not worshipped - "For my flesh is meat indeed, and my blood is drink indeed.” (Hanif, 2011 p.261) Alice Bhatti's breasts, once conjured, are ubiquitous and they inspire some terrible, slavering similes. Hanif seems to rediscover the old instinctive bestiality hidden within the mask of human socialization. The real face behind which never effaces, not even with scientific and epistemic advancement through time. In the statement of Hina Alvi, men's compromised understanding of a wife sounds clearly indicating sexuality framing up the basis of any sacred relationship - "(T)hey think understanding means climbing up a mountain and disappearing into a cave" (Hanif, 2011, p.197). This urge of binary facilitates the corporation of the 'structures of feeling' of the male gaze. The phrase 'structures of feeling' was coined by the famous Marxist critic Raymond Williams which are "... concerned with 'meanings 
and values as they are lived and felt'... often antagonistic both to explicit systems of values and beliefs, and to the dominant ideologies within a society." (Barry, 2010 p.177)

Dr Terry Rey in his essay "Junta, Rape, and Religion in Haiti, 1993-1994" has analysed to illustrate how religion contributes to the cognitive framing of the abuses suffered by females. Based on interviews and campaign programs with the abused, Rey alights on the complicity of religion in the construction of a "rape culture" which mysteriously is followed by a sense of rehabilitation by religion itself. This strange dynamism of human thought does not only incorporate a unifying spirit of living among the terrified and distressed but a diversifying reflex of hatred and revenge as well, which tend to shatter the victim's faith and belief in justice and mankind. On the other hand the military leaders, according to Rey, mechanised sexual abuse as a policy of violence to solidify their political power both in real and perceived state of events (Rey, 1999 p.75). In effect mass-rape disrupts the basic family structure and thereby the agenda of civil society and support for democratic institutions and social change.

\section{Sexuality in the Altar: 'Sister'hood and Divinity}

Under constant assault by 'lewd gestures, whispered suggestions, uninvited hands on her bottom' Alice grows up in French Colony where she was born, Sacred Heart Nursing School where she was trained and the hospital where she works now. In her entire journey of life Alice's self-reflexivity is the counterpart of her tireless endeavor to defend feminine entity in midst of the phallocentric hierarchy of existence. Michel Foucault turned the idea of sexuality upside down with the publication of his The History of Sexuality (1978) where he propounds that sexuality makes us what we are and yet it remains other to our rationality and civility. In spite of being our most fundamental truth marking and occupying our epistemic discipline Sexuality becomes “... an object of great suspicion; the general and disquieting meaning that pervades our conduct and our existence, in spite of ourselves; the point of weakness where evil portents reach through to us; the fragment of darkness that we each carry within us: a general signification, a universal secret, an omnipresent cause, a fear that never ends" (Foucault, 1978 p.69). This is the general suspicion of Alice aligning with her saintly stoicism conjuring up her faith in Lord Yassoo and His miracles purported through her candles and prayers.

Alice's healing power is unworldly for which apparently she is perceived as a divine entity if not worshipped. But the hallelujah hailed for her have deeper implication in the novel. Time and again Hanif pictorially depicts the alluring looks the patients bear on their eyes. They seem more attracted to Alice's body than her beauty, more to her bosoms than her heart as if it is a celebration for procuring of or swallowing out her female body. "Patriarch plays its own distinct part in disfavoring divinatory practices. Moreover, when this European ideology confronted the importance of female diviners in many African religious traditions, this became another area of colonial-indigenous conflict." (Kiboko, 2017 p.17). Thus her supernatural, mystic powers are treated like a witch's necromancy for which she is prejudiced. And she is prejudiced not much for being a Christian lady marrying a Muslim husband than that for being a paramedic with heavy bosoms. A married Muslim nurse is not much better than a single Christian nurse. She may just become a slave multiplied by two, Alvi asserts " '...when your average man hears the word "sister", he gets an erection'." (Hanif, 2011 p.86) Again it reflects that a non-confronting woman equally contributes to the patriarchal dominance over a female body as a lewd man does. Sister Hina Alvi reiterates the necrotic sense of whoredom associated with their profession while she effeminates 
and vulgarize their holy duty of healing a patient with clear sexual indication - "Your bedside manner has really improved... (b)ut there is always room for improvement, so I am assigning you a room where you can really improve. VIP Two. Night shift." (Hanif, 2011 p.8o)

\section{Alice's Body: Metaphor of Determinism}

Throughout the multidimensional freeplay of events Alice Bhatti's body is a battleground of different ideas and ideologies. “...(L)iving a life of an in-house messiah at the Sacred” (Hanif, 2011 p.271), the novelist writes that "(H)er twenty-seven-year-old body is a compact little war zone where competing warriors have trampled and left their marks." (Hanif, 2011 p.256) She is not convinced by the marriage proposal of Teddy Butt with the Mauser gun he carries until and unless he assures his noble feelings - "(T)he world might think it's the love of your flesh. I can understand this world and their thinking... When I think about you, do I think about these milk jugs?... I think of your eyes. I think of your eyes only." (Hanif, 2011 p.101) Long before coming to Sacred, Alice had been accused of an attempt to murder for which she was sentenced to imprisonment into the Borstal for fourteen months. Awhile the trial the advocate whispers into the ear of Joseph Bhatti, her father - "'Your daughter is very pretty'...Joseph feels sad: that's all his daughter is good at, looking pretty and bashing up octogenarian professionals. As if being beautiful gives her the right to behave badly." (Hanif, 2011 p.71) By all means the primary concern of a male-dominated society is always to restrict unfettered sexual expression of the female body herself, and more particularly to bring female sexuality under control (Labovitz, 2012 p.84). And the 'male gaze' determine any sexual imperative in terms of the female flesh thus identifying the body a centrifugal composite of discrimination.

Sexual violence is often a consequence of discriminated power equations both actual and recognized between men and women. At the same time the underdevelopment and terror-ridden condition of this South Asian continent exhibits this tendency along with the primordial hermeneutic. The furious acid-throwing upon Alice by her loving husband seals the tempestuous frustration of a degenerated man in quest of self-actualization. Thus after being targeted to rape in the VIP room of the hospital, Alice cuts the genital organ of Junior and boldly directs him - "Go to Accidents. And no need to be shy, they get lots of this sort of thing during their night shift." (Hanif, 2011 p.89) Identity establishment in terms of equality in gender is the first thing Alice seems to counter against. She even does not spare her Choohra father when he talks about the sign of a baby girl's femininity. Alice slaps at the face of our $21^{\text {st }}$ century civilization - " 'Sign of what? I think it's a sign that there is no place a woman can go and deliver a baby, that there is no place for her even when her water is breaking. It's a sign that human life can be flushed down the toilet'." (Hanif, 2011 p.73) Hanifs pinpointed satire affirms the status quo of a male, chauvinistic societal construction within which sexual violence is not merely an oxidation of terrorism but also a means to scratch perennial wound over human psychodynamics.

\section{Counterfeiting the Allegory of Gender and Religion: Humanity over Sainthood}

Within her speaking back to the subjugating forces Alice becomes a soldier of humanism with her belief in Lord Yassoo. She does realize the true nature of human faith over supernatural power or the touch of healing - "People will believe what they want to believe. I am only doing my job." (Hanif, 2011 p.276) Alice concludes a new paradigm of faith in order to bridle the dominating discourses of a religious belief - "What use was your faith if it didn't give you the strength and 
skills to break a few bones?" (Hanif, 2011 p.254). This confident pronouncement for any religious minority substantiates her saintly ideology dovetailed upon humanity. The newspaper Catholic Courier authenticates sainthood by entitling her as a 'soldieress of Yassoo'. She coordinates a renewed metaphor for miracles, faith in God reminding that as the basis of the clash among civilizations - " ' $(\mathrm{O})$ ne needs to be specific. Especially if it's God's word. It can be dangerous if it's vague...” (Hanif, 2011 p.236).

The incident of the miracle she performs unsettles her just like the consequence of the gaze of “... the people who now look at her as if she isn't a diligent professional who occasionally goes beyond the call of her duty, but a messiah who has forsaken her right to a regular lunch break." (Hanif, 2011 p.246) Yet she does not fail back in her deliverance and love to Lord Yassoo. The novel describes that "She didn't just believe in the Holy Spirit, she possessed it and didn't believe in sharing." (Hanif, 2011 p.250) Love is bound to be possessive and this is the newness of the connotation of sainthood acclaimed by the author. It could be reminiscent of Hina Alvi's struggle for survival as a single woman connoting “... a whole religion itself, with its own rituals. It has its own damnation and rewards" (Hanif, 2011 p.299) from where she never recedes.

\section{Conclusion}

Mohammed Hanif s angry humor does not just question the traditional norms of sainthood, it also undermines the discourses we have come to accept as 'normal'. Alice Bhatti procreates a new humanistic dimension of religiosity and sainthood in a flummoxed space of cultural temperament full of fanatics. The idealized, perfected and imaginary view of Reformation is no more in today's world, and of course in an Islamist society like that of Pakistan, as evident from the consequences of Alice. She discards the 'spectre of the veil' (Khair et al, 2008 p.218) from a subaltern, ChristoMuslim, convicted 'sister' strangulated in a patriarchal space, to cleanse the inevitable dirt of a profession and gender, because "...the cleansing is inevitable, and the tide of reform cannot be stopped. The Islamic Reformation is already here.” (Aslan, 2011 p.292) In the Epilogue Joseph Bhatti urges a letter for her congregation - "Here our poor Alice Bhatti cures the incurable and is declared a common criminal." (Hanif, 2011 p.337) This letter is no doubt an open subscription to the reader's rationale, thus Alice herself becomes canonized, if not dead.

\section{References}

Aslan, Reza. (2011). No God But God: The Origins, Evolution and Future of Islam. London: Arrow Books.

Barry, Peter. (2017). Beginning Theory: An Introduction to Literary and Cultural Theory. Manchester: Manchester University Press.

Bartlett, Robert. (2013). Why Can the Dead do Such Great Things?: Saints and Worshippers from thr Martyrs to the Reformation. Princeton: Princeton University Press.

Foucault, Michel. (1978). The History of Sexuality, volume I: An Introduction. Trans. Robert Hurley.New York: Vintage Books.

Hanif, Mohammed. (2011). Our Lady of Alice Bhatti. Noida: Random House India. 
Khair, Tabish, \& Verma, Renu K. (2008). Muslim modernities: Tabish Khairs essays on moderation and mayhem 2001-2007. New Delhi: Vitasta Pub.

Kiboko, J. Kabamba. (2017). Divining the Woman of Endor: African Culture, Postcolonial Hermeneutics, and the Politics of Biblical Translation. New York: Bloomsbury T\&T Clark.

Labovitz, Gail. (2012). "More Slave Women, More Lewdness: Freedom and Honor in Rabbinic Constructions of Female Sexuality". Journal of Feminist Studies in Religion, Vol. 28, No. 2: 69-87. Retrieved 23 March, 2018 from http://www.jstor.org/stable/10.2979/jfemistudreli.28.2.69

Murray, Jacqueline. (1997). “Men’s Bodies, Men’s Minds: Seminal Emissions and Sexual Anxiety in the Middle Ages". Annual Review of Sex Research, 8(1): 1-26. Retrieved 10 Jan, 2018 from http://www.tandfonline.com/doi/abs/10.1080/10532528.1997.10559917

Rey, Terry. (1999). “Junta, Rape, and Religion in Haiti, 1993-1994”. Journal of Feminist Studies in Religion, Vol. 15, No. 2: 73-100. Retrieved 15 Feb, 2018 from http://www.jstor.org/stable/25002366

Sehgal, Parul. (2012, June 15). "Interpreter of Maladies: 'Our Lady of Alice Bhatti', by Mohammed Hanif”. Sunday Book Review in The New York Times. Retrieved 1o Aug, 2016 from https://www.nytimes.com/2012/o6/17/books/review/our-lady-of-alice-bhatti-by-mohammedhanif.html

Spivak, Gayatri Chakravorty. (1988). “Can the Subaltern Speak?”. In Cary Nelson and Lawrence Grossberg (ed), Marxism and the Interpretation of Culture (pp. 271-313). Urbana: University of Illinois Press. Vauchez, André. (2005). Sainthood in the later middle ages. Cambridge: Cambridge University Press. Walters, Eric. (2012). Between Heaven and Earth. Retrieved from http://books.google.com.

\begin{abstract}
About the Authors
${ }^{1}$ Sourav Paul, a student of English literature and a UGC Junior Research Fellow, is presently pursuing his Ph.D in Arts (English Literature) at the Department of Humanities and Social Sciences in National Institute of Technology Durgapur, India under the supervision of Dr Shri Krishan Rai. He has been keenly interested to probe into the post 9/11 South Asian studies. A Sangeet Prabhakar in Indian Classical Music (vocal) from Prayag Sangeet Samiti Allahabad, Sourav is interested in poetry, music and contemporary literary theories. He has got two papers and many a poems in international journals.
\end{abstract}

${ }^{2}$ Dr Shri Krishan Rai is an Assistant Professor of English at the Department of Humanities and Social Sciences in National Institute of Technology Durgapur, West Bengal, India. He has delivered talks at the Universities of Oxford, La Laguna, and Allahabad among many others. He has got three books, a score of research papers in reputed national and international journals to his credit to date and contributed chapters to several anthologies on literature. His current interests include cinema, religion and contemporary theories. 